\title{
Characterization of crystalline phases of bone ash
}

\author{
M. Ahsan*, A. H. Dewan, S. Mustafi and S. Ahmed \\ Institute of Glass and Ceramic Research and Testing (IGCRT), Bangladesh Council of Scientific and Industrial \\ Research (BCSIR), Dr. Qudrat-i-Khuda Road, Dhanmondi Dhaka - 1205, Bangladesh
}

\begin{abstract}
Bone ash has been prepared from waste cattle bone choosing two different calcination temperatures $\left(1050{ }^{\circ} \mathrm{C}\right.$ and $\left.1100{ }^{\circ} \mathrm{C}\right)$. The heat treatment was performed by conducting quenching and without quenching techniques. The prepared bone ash was characterized using XRF, XRD and FTIR techniques which revealed that the observed data were in excellent agreement with the standard values for hydroxyapatite (the prime raw material of bone china) and could be used as the raw material for bone china ceramic ware.
\end{abstract}

Keywords: Characterization, Bone ash, XRF, XRD, FTIR

\section{Introduction}

Bovine ash is the prime raw material for the fabrication of bone china, which is a very special and attractive porcelain ware throughout the world. The particular characteristics of bone china include whiteness, translucency, decoration quality, bright glaze and high strength. However, all these properties are strictly dependent on the quality of the raw materials used to fabricate bone china body. Traditionally bone china is produced using the raw materials bone ash, china clay and cornish stone [Gouvêa et al. 2009, Kara and Stevens 2002, Miyahara et al. 2007, Weyl 1941]. However, compositions of these raw materials may vary from one company to another but the constituents are within the approximate weight ratio of 2:1:1 respectively [Kara and Stevens 2002]. The minerals and oxides generally used in the manufacture of bone china are shown in Table I [Kara and Stevens 2002].

Table I : Weight \% of minerals and oxides used in bone china

\begin{tabular}{lllc}
\hline Raw material & Mineral & Oxides & Wt \% \\
\hline Bone ash & Hydroxyapatite & $\mathrm{Ca}_{10}\left(\mathrm{PO}_{4}\right)_{6}(\mathrm{OH})_{2}$ & 50 \\
China clay & Kaolinite & $\mathrm{Al}_{2} \mathrm{O}_{3} 2 \mathrm{SiO}_{2} 2 \mathrm{H}_{2} \mathrm{O}$ & \\
& Feldspar & $\mathrm{K}_{2} \mathrm{O} \mathrm{Al}_{2} \mathrm{O}_{3} 6 \mathrm{SiO}_{2}$ & 25 \\
Cornish stone & Quartz & $\mathrm{SiO}_{2}$ & \\
& Mica & $\mathrm{K}_{2} \mathrm{O}_{3} \mathrm{Al}_{2} \mathrm{O}_{3} 6 \mathrm{SiO}_{2} 2 \mathrm{H}_{2} \mathrm{O} 25$ \\
\hline
\end{tabular}

The traditional process of bone ash production is a combination of few steps which include: removal of meat, protein etc. using hot water, steam, solvents followed by drying and calcination at high temperature in order to remove organic constituents [Gouvêa et al. 2009]. The final product thus obtained is basically known as calcium hydroxyapatite (HA). However in addition to thermal decomposition, subcritical water process and alkaline hydrolysis are also used to extract HA from animal bone [Barakat et al. 2009, Ooi et al. 2007, Sobczak et al. 2009].

Although in Bangladesh the demand of bone china porcelain ware is extremely high compared to any other ceramic ware, but unfortunately the ceramic industries of this country are importing the raw materials to produce bone china porcelain ware. This import business costs a lot of foreign exchange which obviously affects the country's economy. However in the perspective of Bangladesh a developing country, this bone china porcelain ware industry can flourish significantly. Because huge amount of raw bones are abundant in our country which could be the potential source of raw materials for bone china porcelain ware. However to develop a costeffective and optimized process for the fabrication of bone china, a number of factors e.g. temperature of heat treatment, time etc. need to be investigated properly, but unfortunately these are not well justified in the literature [Gouvêa et al. 2009]. From these points of views, in this paper an attempt has been taken to develop an effective protocol to prepare bone ash using waste cattle bone, which will also open up another way of material recycling technology for future waste management. 


\section{Materials and Methods}

The raw bones were collected from a local butcher shop and cleaned by removing spongy bones, bone marrow, any trace of meat and fat etc. It was then heat treated with steam at $100^{\circ} \mathrm{C}$ to get rid of any unwanted materials, blood content etc. This cleaning procedure followed by drying at $100{ }^{\circ} \mathrm{C}$ and the bones were crushed into small chips. These bone chips were treated at $1050{ }^{\circ} \mathrm{C}$ and $1100{ }^{\circ} \mathrm{C}$ temperatures using a $2{ }^{\circ} \mathrm{C} \mathrm{min}^{-1}$ ramp and $30 \mathrm{~min}$ soaking time. The heat treatment was performed by conducting quenching and without quenching techniques. Complete burning of organic matters was ensured by providing air flux inside the furnace. The heat treated bone chips were transformed to fine powder through ball mill operation for 2 hrs and then subjected to various physical and chemical analyses.

Elemental analysis of the heat treated bone ash was performed by x-ray fluorescence spectroscopy (XRF) while the functional groups were identified by fourier transform infrared spectrometer (FTIR). The experimental spectra were recorded by using $\mathrm{KBr}$ disks (sample-to- $\mathrm{KBr}$ ratio = $1: 100)$ and the samples were scanned in the wave number range of $4000 \mathrm{~cm}^{-1}-400 \mathrm{~cm}^{-1}$. The spectrometer had a resolution of $4 \mathrm{~cm}^{-1}$. Phase analysis of the bone ash samples was carried out by x-ray diffractometer (XRD). The intensity data were collected in $0.02^{\circ}$ steps following the scanning range of $2 \theta=20^{\circ}-80^{\circ}$ using $\mathrm{CuK} \alpha\left(\lambda=1.54178^{\circ} \mathrm{A}\right)$ radiation. The phases were compared with the standard JCPDS files.

\section{Result and Discussion}

As a preliminary step of physical characterization the density of the calcined bone ash powder was calculated. The observed values as summarized in Table II show that only the density of bone ash powder calcined at $1100{ }^{\circ} \mathrm{C}$ without quenching condition is in good agreement with the standard density value of hydroxyapatite $\left(3.145 \mathrm{~g} / \mathrm{cm}^{3}\right)$ [Bahrololoom et al. 2009]. Hence this bone ash sample was further subjected to XRF, XRD, FTIR and SEM analyses.

Table II: Physical properties of bone ash

\begin{tabular}{lcccc}
\hline Temperature & \multicolumn{1}{c}{$1050{ }^{\circ} \mathrm{C}$} & \multicolumn{2}{c}{$1100{ }^{\circ} \mathrm{C}$} \\
\hline & Quenching & $\begin{array}{c}\text { Without } \\
\text { Quenching }\end{array}$ & quenching & $\begin{array}{c}\text { Without } \\
\text { quenching }\end{array}$ \\
$\begin{array}{l}\text { \% of loss on } \\
\text { ignition }\end{array}$ & 3.18 & 3.33 & 3.95 & 4.04 \\
Density g/cc & 0.24 & 2.60 & 0.27 & 3.24 \\
\hline
\end{tabular}

The chemical composition of this bone ash sample as investigated by XRF is shown in Table III. Clearly the principal chemical constituents are within the expected range as observed previously [Gouvêa et al. 2009, Bahrololoom et al. 2009, Haberko et al. 2006]. The slight discrepancy of these observed values could be due to the different type of bone used. The bones were purchased from the local market and hence the exact information about the breed and age of the cattle are unknown. Although these information acts as the influential parameters in regulating the composition of HA in the calcified tissues. However, the negligible presence of iron content $(0.01 \%)$ ensures the application of this raw material to achieve optimal visual properties of bone china. Because iron affects the whiteness of bone china as a colouring impurity.

Table III: Chemical analysis of bone ash sample treated at $1100{ }^{\circ} \mathrm{C}$

\begin{tabular}{cc}
\hline Parameters & Amount present in \% \\
\hline $\mathrm{SiO}_{2}$ & 2.40 \\
$\mathrm{Al}_{2} \mathrm{O}_{3}$ & 2.34 \\
$\mathrm{Fe}_{2} \mathrm{O}_{3}$ & 0.14 \\
$\mathrm{CaO}$ & 53.00 \\
$\mathrm{SO}_{3}$ & 0.30 \\
$\mathrm{MgO}$ & 1.52 \\
$\mathrm{Na}_{2} \mathrm{O}$ & 1.08 \\
$\mathrm{~K}_{2} \mathrm{O}$ & 0.15 \\
$\mathrm{ZrO}$ & 0.00 \\
$\mathrm{BaO}$ & 0.14 \\
$\mathrm{P}_{2} \mathrm{O}_{5}$ & 38.19 \\
\hline
\end{tabular}

The result of FTIR analysis is tabulated in Table IV. It is observed from the FTIR data that the observed bands are in well matched position representing the phosphate group as found in previous investigation [Zaki et al. 2006, Tas 2000, $\mathrm{Xu}$ et al. 2001] where the author also observed the presence

Table IV: FTIR of calcined $\left(1100{ }^{\circ} \mathrm{C}\right)$ bone ash sample (without quenching)

\begin{tabular}{ccc}
\hline $\begin{array}{c}\text { Observed band } \\
\text { position }\left(\mathrm{cm}^{-1}\right)\end{array}$ & $\begin{array}{c}\text { Corresponding } \\
\text { assignments }\end{array}$ & $\begin{array}{c}\text { References to match the } \\
\text { observed band positions }\end{array}$ \\
\hline 462.9 & $\mathrm{PO}_{4}{ }^{3-}\left(v_{2}\right)$ & Tas 2000, Xu et al. 2001, \\
567.0 & $\mathrm{PO}_{4}^{3-}\left(v_{4}\right)$ & Haberko et al. 2006, \\
603.7 & $\mathrm{PO}_{4}{ }^{3-}\left(v_{4}\right)$ & Joschek et al. 2000 \\
947.0 & $\mathrm{PO}_{4}{ }^{3-}\left(v_{3}\right)$ & \\
979.8 & $\mathrm{PO}_{4}{ }^{3-}\left(v_{3}\right)$ & \\
1458.1 & $\mathrm{CO}_{3}{ }^{2-}$ & \\
\hline
\end{tabular}


of phosphate group in $v_{3}$ and $v_{4}$ mode at $1150-963 \mathrm{~cm}^{-1}$ and $655-548 \mathrm{~cm}^{-1}$ respectively. A small peak at band position $1458.1 \mathrm{~cm}^{-1}$ could be due to the $\mathrm{CO}_{3}{ }^{2-}$ group. Since the presence of $\mathrm{CO}_{3}{ }^{2-}$ group is a common impurity effect in both synthetic and natural hydroxyapatite [Haberko et al. 2006, Joschek et al. 2000].

A typical XRD diffraction of bone ash sample is presented in Figure 1. The diffractogram ensures the presence of hydroxyapatite (HA) having hexagonal structure (space group $\left.\mathrm{P}_{3} / \mathrm{m}\right)$ as the dominant phase with the characteristic $2 \theta$ positions at $31.88296^{\circ}\left(\begin{array}{lll}2 & 1 & 1\end{array}\right), 32.1828^{\circ}\left(\begin{array}{lll}1 & 1 & 2\end{array}\right)$ and is quite satisfactory because at $1000^{\circ} \mathrm{C}-1100^{\circ} \mathrm{C}$ sintering temperature, HA usually forms crystallized $\beta$-TCP according to the following equation.

$\mathrm{Ca}_{10}\left(\mathrm{PO}_{4}\right)_{6}(\mathrm{OH})_{2} \rightarrow 3 \mathrm{Ca}_{3}\left(\mathrm{PO}_{4}\right)_{2}+\mathrm{CaO}+\mathrm{H}_{2} \mathrm{O}$

The lattice parameters for both phases were calculated considering the Bragg reflections at ( $\left.\begin{array}{lll}0 & 0 & 2\end{array}\right),\left(\begin{array}{lll}3 & 0 & 0\end{array}\right)$ planes and ( $\left.\begin{array}{lll}0 & 2 & 10\end{array}\right),\left(\begin{array}{lll}3 & 0 & 0\end{array}\right)$ planes for HA and $\beta$-TCP respectively. The volume of the hexagonal unit cell for HA and the rhombohedral unit cell for $\beta$-TCP were calculated using Equations 2 and 3 [Ahmed et. al 2008] respectively.

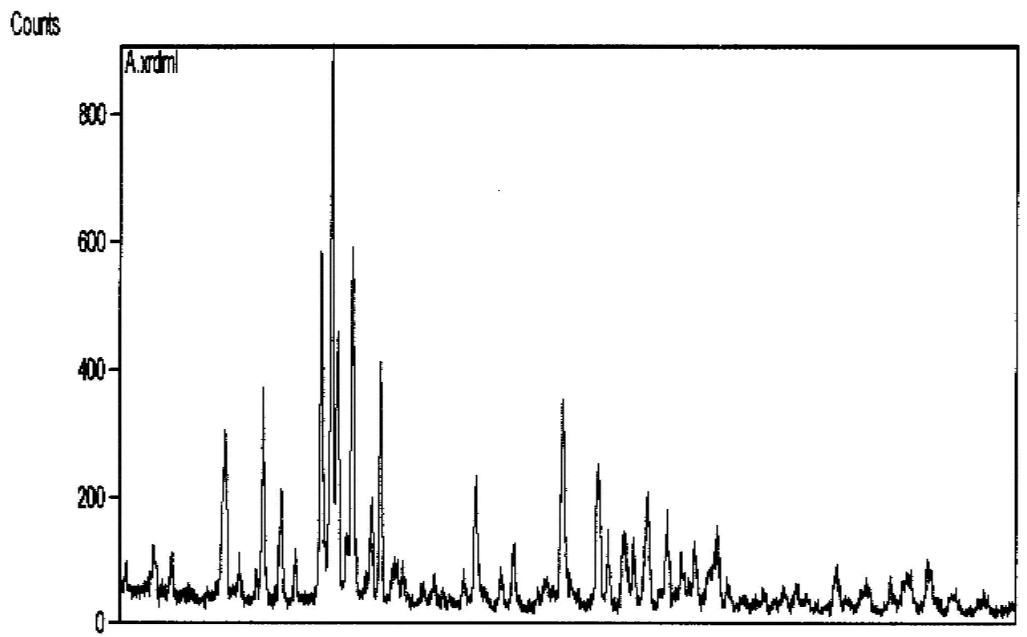

Fig. 1: XRD of calcined $\left(1100{ }^{\circ} \mathrm{C}\right)$ bone ash sample (without quenching)

$32.9927^{\circ}$ (3 00 ). On the other hand $\beta$-TCP is also indexed as mixed phase (JCPDS File \# 09-0169) having rhombohedral structure (space group R3c) [Ahmed et. al 2008]. Particularly the diffraction peaks at $2 \theta$ positions 29.8314 (3 00 ), 31.2638 (0 2 10) and 34.5834 (2 20 ) plane confirmed the presence of $\beta$-TCP along with the HA. This observation

$$
\begin{aligned}
V & =2.589 a^{2} \mathrm{c} \\
\text { and } \quad V & =0.866 a^{2} \mathrm{c}
\end{aligned}
$$

The crystallite sizes of HA and $\beta$-TCP were determined from Scherrer's relationship $\mathrm{D}=79.5 / \Delta \cos \theta$, where $\mathrm{D}=$

\begin{tabular}{|c|c|c|c|c|c|}
\hline \multirow[t]{2}{*}{ Sample } & \multirow[t]{2}{*}{ Phase and symmetry } & \multicolumn{2}{|c|}{ Lattice constants $\left({ }^{\circ} \mathrm{A}\right)$} & \multirow[t]{2}{*}{ Unit cell volume, $V\left({ }^{\circ} \mathrm{A}\right)$} & \multirow[t]{2}{*}{ Crystallite sizes, $\mathrm{nm}$} \\
\hline & & $a=b$ & $c$ & & \\
\hline \multirow[t]{4}{*}{ Bone ash } & HA & & & & \\
\hline & Hexagonal & 9.41 & 6.88 & 1577.25 & 42.0 \\
\hline & $\beta-\mathrm{TCP}$ & 10.37 & 37.12 & 3457.11 & 84.6 \\
\hline & Rhombohedral & & & & \\
\hline JCPDS & HA & 9.42 & 6.88 & 1580.84 & \\
\hline $\begin{array}{l}\text { File \# 09- } \\
0432\end{array}$ & Hexagonal & & & & \\
\hline JCPDS & $\beta$-ТCP & 10.43 & 37.38 & 3520.91 & \\
\hline $\begin{array}{l}\text { File \# 09- } \\
0169\end{array}$ & Rhombohedral & & & & \\
\hline
\end{tabular}
crystal size $\left({ }^{\circ} \mathrm{A}\right), \Delta=$ FWHM in degree. The crystallo

Table V: Crystallographic parameters of the bone ash sample 
graphic parameters of the bone ash sample were compared with the standard JCPDS files and summarized in Table V. The data shown in Table V indicates that although the crystallographic parameters for HA matches with the standard value but in case of $\beta$-TCP the values slightly differs from the standard values which could be due to formation of $\beta$ TCP in poor crystalline form.

\section{Acknowledgement}

The authors are grateful to the IGCRT, BCSIR authority for financial support.

\section{References}

Ahmed S and Ahsan M (2008). Synthesis of Ca-hydroxyapatite bioceramic from egg shell and its characterization, Bangladesh J. Sci. Ind. Res. 43(4): 497 - 508.

Ahmed S and Ahsan M (2008). Structural characterization of Ca-phosphate bio-ceramics from egg shell, Proceeding of the Bangladesh Chemical Congress, 160-166.

Bahrololoom ME, Javidi M, Javadpour. S and Ma J (2009). Characterization of natural hydroxyapatite extracted from bovine cortical bone ash, J. Ceram. Proc. Res., 10(2): 129 - 138.

Barakat NAM, Khil MS, Omran AM, Sheikh FA and Kim HY (2009). Extraction of pure natural hydroxyapatite from the bovine bones biowaste by three different methods, J. Materials Processing Technology, 209(7): $3408-3415$.

Gouvêa D, Alatrista GAV, Brito SLM, Castro RHR and Kahn H (2009). Surface modification of bovine bone ash prepared by milling and acid washing process, Ceramics International, 35: 3043 - 3049.

Haberko K, Bucko MM, Brzezinska-Miecznik. J, Haberko M, Mozgawa W, Panz T, Pyda A and Zarebski J, (2006). Natural hydroxyapatite - its behaviour during heat treatment, J. Euro. Ceram. Soc., 26(4-5): 537-542.

Joschek S, Nies B, Krotz R and Gopferich A (2000). Chemical and physicochemical characterization of porous hydroxyapatite ceramics made of natural bone, Biomaterials, 21: 1645 - 1658.
Kara A and Stevens R (2002). Characteruzation of biscuit fired bone china body microstructure. Part I: XRD and SEM of crystalline phases, J. Euro. Ceram. Soc., 22: 731-736.

Miyahara RY, Gouvêa D and Toffoli SM (2007). Preparation and characterization of bovine bone ash for the fabrication of bone china. Cerâmica, 53(327): 234-239.

Ooi CY, Hamadi M and Ramesh S. (2007). Properties of hydroxyapatite produced by annealing of bovine bone, Ceramics International, 33: 1171 - 1177.

Sobczak A, Kowalski Z and Wzorek Z (2009). Preparation of hydroxyapatite from animal bone, Acta of Bioengineering and Biomechanics, 11(4): 23-28.

Tas, AC (2000). Synthesis of biomimetic Ca-hydroxyapatite powders at $37^{\circ} \mathrm{C}$ in synthetic body fluids, Biomaterials, 211429.

Weyl WA (1941). Phosphates in ceramic ware: II, Role of phosphorus in bone china, Journal of the American Ceramic Society, 24: 245-247.

$\mathrm{Xu}, \mathrm{G}$, Aksay, IA and Groves JT (2001). Continuous Crystalline Carbonate Apatite Thin Films. A Biomimetic Approach, J. Am. Chem. Soc., 1232196.

Zaki. MI, Knozinger H, Tesche B and Mekhemer GA H (2006). Influence of phosphonation and phosphonation on surface acid-base and morphological properties of $\mathrm{CaO}$ as investigated by in situ FTIR spectroscopy and electron microscopy, J. Colloid Inter. Sci., 303(1): $9-17$.

Received : 19 January 2011; Revised : 24 April 2012; Accepted: 15 May 2012. 